\title{
DIPLODON CHILENSIS GRAY, 1828 (BIVALVIA: HYRIIDAE) A POTENTIAL RESIDUAL WATERS DEPURATOR ON INLAND WATER SALMONID FISH- FARMS: ALABORATORY SCALE STUDY
}

\section{DIPLODON CHILENSIS GRAY, 1828 (BIVALVIA: HYRIIDAE) UN POTENCIAL DEPURADOR DE AGUAS RESIDUALES DE PISCICULTURA DE SALMONIDOS DE AGUAS CONTINENTALES: UNESTUDIOAESCALADE LABORATORIO}

\author{
Esperanza Parada ${ }^{1}$, Santiago Peredo ${ }^{1}$, Silvia Cárdenas ${ }^{1}$, Iván Valdebenito² \& Matías Peredo ${ }^{3}$ \\ ${ }^{1}$ Escuela de Ciencias Ambientales. ${ }^{2}$ Escuela de Acuicultura, Facultad de Recursos Naturales, \\ Universidad Católica de Temuco, Mail Box 15-D, Temuco, Chile. email:eparada@uct.cl \\ ${ }^{3}$ Depto. de Ingeniería Hidráulica y Medio Ambiente, Universidad Politécnica de Valencia, España.
}

\begin{abstract}
The aim of the present study was to experimentaly evaluate the capability of the freshwater mussel Diplodon chilensis as a potential depurator of residual waters in fish farming. With this purpose, the present study was carried out at the fish farm of the School of Aquaculture of the Catholic University- Temuco, Chile (38 $46^{\prime}$ 'S; $72^{\circ} 38^{\prime} \mathrm{W}$ ). The experimental design consisted of 12 poly vinyl chloride trays of 50x20x20cm corresponding to 3 treatments with 3 replicates each treatment and their respective controls. Each tray contained sterilized sand substratum and running water from a trout feeding tank. The treatments 1, 2, 3 contained 15, 30 and 60 mussels respectively, while the control trays contained no mussels. The growth tank contained $5,2 \mathrm{k} / \mathrm{m}^{3}$ of Oncorhynchus mykiss. The trouts were fed daily with $37 \mathrm{~g}$ of fish food during the time of the experiment duration. At time 0 the wet weight and length of each mussel was measured to determine the physiological state of the specimens through the Condition index. At the onset of the experiment it was determined the mortality and the Condition index of each individual. Also water samples from each tray corresponding to the 3 treatments, their respective replicates and controls were taken at time 0,30 and 60 days to determine: total suspended solids, total dissolved solids, dissolved oxygen, total phosphorous, ammonium, nitrite, nitrate, conductivity, temperature, $\mathrm{pH}$ and chemical oxygen demand (COD). In a parallel way the percentage of organic matter and COD in the substratum of each of the treatment trays and their respective controls were determined. D. chilensis showed more efficiency in diminishing the concentrations of total suspended solids, total phosphorous, nitrite and the chemical oxygen demand. Values of the mentioned parameters decreased in direct relation to mussel density and time elapsed. Water COD data showed a high system efficiency percentage, corroborated by the substrate organic matter and substrate CDO data. These results, valid for an experimental scale show that $D$. chilensis is efficient in water depurator used on fish farming activities, suitable for rural fish farming.
\end{abstract}

Keywords: Hyriidae, freshwater mussel, Diplodon chilensis, residual waters depuration, rural salmonid fish-farms.

\section{RESUMEN}

El objetivo del presente estudio fue evaluar experimentalmente la capacidad de uso de la almeja de agua dulce Diplodon chilensis como potencial depurador de aguas residuales de pisciculturas continentales. Con este propósito, el presente estudio fue realizado en la piscicultura de la Escuela de Acuicultura de la Universidad Católica de Temuco, Chile (3846’S; 72³8’W). El diseño experimental consistió de 12 bandejas de PVC de 50x20x20 cm correspondientes a 3 tratamientos con 3 réplicas cada uno y sus respectivos controles. Cada bandeja contenía arena esterilizada como sustrato y agua corriendo proveniente de un estanque de crecimiento de truchas. Los tratamientos 1, 2 y 3 contenían 15, 30 y 60 especímenes respectivamente, en tanto que los controles no contenían almejas. El estanque de crecimiento contenía 5,2k/m³ de Oncorhynchus mykiss. Las truchas fueron alimentadas diariamente con 37g de alimento para peces durante el tiempo de duración del experimento. A tiempo 0, se determinó el peso húmedo y la longitud valvar de cada individuo para determinar su estado fisiológico a través del Indice de Condición. Al final del experimento se determinó la mortalidad y el Indice de Condición de cada individuo. A tiempo 0, 30 y 60 días se tomaron muestras de agua de cada bandeja de cada tratamiento, de las réplicas y de sus respectivos controles para determinar sólidos suspendidos 
Diplodon chilensis a potential depurator: PARADA, E. ET AL.

totales, sólidos disueltos totales, oxígeno disuelto, fósforo total, amonio, nitrito, nitrato, conductividad, temperatura, pH y demanda química de oxígeno. Paralelamente se determinó el porcentaje de materia orgánica y la demanda química de oxígeno del sustrato de cada tratamiento y sus respectivos controles. $D$. chilensis mostró más eficiencia en disminuir las concentraciones de sólidos suspendidos totales, fósforo total, nitrito y demanda química de oxígeno. Los valores de los parámetros mencionados disminuyeron en relación con la densidad de almejas y el tiempo transcurrido del experimento. Los valores obtenidos de demanda química de oxígeno muestran una alta eficiencia del sistema, corroborado por los valores obtenidos de materia orgánica y demanda química del sustrato. Estos resultados, válidos a escala experimental, muestran que $D$. chilensis es un eficiente depurador de aguas provenientes de actividades piscícolas, y adecuado para pisciculturas rurales.

Palabras claves: Hyriidae, almeja de agua dulce Diplodon chilensis, depuración de aguas residuales, pisciculturas rurales de salmónidos.

\section{INTRODUCTION}

The success of the fish farming in Chile has been the high quality of the water of rivers and mountain lakes. According to Soto (2002) these temperate aquatic systems are very low in chlorophyll-a concentration, high water transparency, low productivity and some apparent resistance to disturbance such as phosphorus additions. However, this high quality water has been deteriorating because the residual waters of the fish farming centers are poured to the same rivers and lakes with consequences to the aquatic ecosystem such as eutrophication, siltation and others (Parada \& Peredo 2005).

At fish farming centers a great deal of the food which is not consumed by fish is dragged to the bottom of the growth tanks or to the substrate in the form of sediments. Another important amount of food which is not assimilated by fish is eliminated as faeces. Both elements return to the environment provoking eutrophication in the aquatic ecosystem (Beveridge 1996). Considering these facts, environmental fish farming management in Chile is focused on diminishing or recycling residual sediments. Besides new diets are under investigation to improve fish convertion rates (Poniak et al. 2004). It has been estimated that approximately $70 \%$ of $\mathrm{P}$ and $30 \%$ of $\mathrm{N}$ of food is not assimilated by fish and released to the environment (Soto \& Mena 1999), with the adverse consequences to the recipient aquatic systems. The management of residues points towards the use of sedimentation ponds to separate the solid sediments to then return the water to its natural course. An alternative to this kind of treatment is the use of biofilters, making use of species of well known filtering efficiency.

Freshwater mussels are widely known as filter feeders by removing suspended organic particulates, detritus and phytoplankton. Although most published works on filter feeding have focused on marine bivalves, some work has been done with freshwater bivalves, particulary Dreissena polymorpha (Reeders et al. 1989, Reeders \& Bij de Vaate 1990, Bunt et al. 1993). However, the main problem with this mussel is its ability to foul all kinds of submerged aquatic structures and its fast spreading ability, which make it a problematic invasive species (Herber et al. 1991, Griffiths et al. 1991).

The commonest species of native freshwater mussel in Chile is Diplodon chilensis (Gray, 1828), with a distribution in the country extending from $30^{\circ} 28^{\prime} \mathrm{S}$ to $46^{\circ} 37^{\prime} \mathrm{S}$ in both lentic and lotic environments in a number of hydrographic basins; it is also present in Argentina between $32^{\circ} 52^{\prime} \mathrm{S}$ and $45^{\circ} 51^{\prime} \mathrm{S}$ (Parada \& Peredo 2002, Parada et al. 2007). The filter role of this specie in the ecosystem function has been amply documented. For instances, Valdovinos \& Cuevas (1996) have calculated the filtering efficiency of $D$. chilensis through measurement of the clearing rate in laboratory conditions estimating values of $1.99(0.43)$ $\mathrm{ml} \mathrm{min}^{-1}$ ind $^{-1}$, in specimens of 32 to 39 mm length. Lara et al. (2002a) showed the capacity of diminishing the turbidity of the water and to digest fecal coliforms. Given the efficient filtering characteristics of the $D$. chilensis the objective of this study was to experimentally evaluate the capability of $D$. chilensis as potential purifier of residual waters in small volumen as in rural fish farming.

\section{MATERIALSAND METHODS}

STUDY SITE AND SAMPLING METHHOD

The lake Colico ( $39^{\circ} 07^{\prime} \mathrm{S} ; 7^{\circ} 00 \mathrm{~W}$ ) in the pre Andes Mountains region is part of the Chilean northernpatagonian lakes denominated Araucanian lakes. It belongs to the Toltén river basin. It is pristine, oligotrophic and with low productivity (Soto 2002). In summer, its temperature ranges between $19.5^{\circ} \mathrm{C}$ 
and $21^{\circ} \mathrm{C}$ and in winter, between $9.2^{\circ} \mathrm{C}$ and $9.4^{\circ} \mathrm{C}$. Its maximum depth is $250 \mathrm{~m}$.

The sampling method consisted to collect qualitative and randomly three hundred and fifteen mussels by scuba diving at 2m depth in April 2005 from Lake Colico and then transported into coolers of $40 \times 25 \times 35 \mathrm{~cm}$ with lake water to the hatchery of the School of Aquaculture of the Catholic University of Temuco, Chile (3846's; $72^{\circ} 38^{\prime} \mathrm{W}$ ). The water temperature of coolers was $9^{\circ} \mathrm{C}$ and all mussels survived the transportation.

\section{EXPERIMENTAL DESING}

The experiment design consisted of a total 12 poly vinyl chloride(PVC) trays of 50x20x20 cm corresponding to 3 treatments with 3 replicates each treatment and their respective controls. Each tray contained sterilized sand substratum and received running water from a trout feeding tank. The treatment 1 (T1) contained 15 mussels (with a biomass equivalent to 282g), T2 contained 30 mussels (with a biomass equivalent to 564g) and T3 contained 60 mussels with a biomass equivalent to 1,128g, while the control trays contained no mussels (Fig. 1).

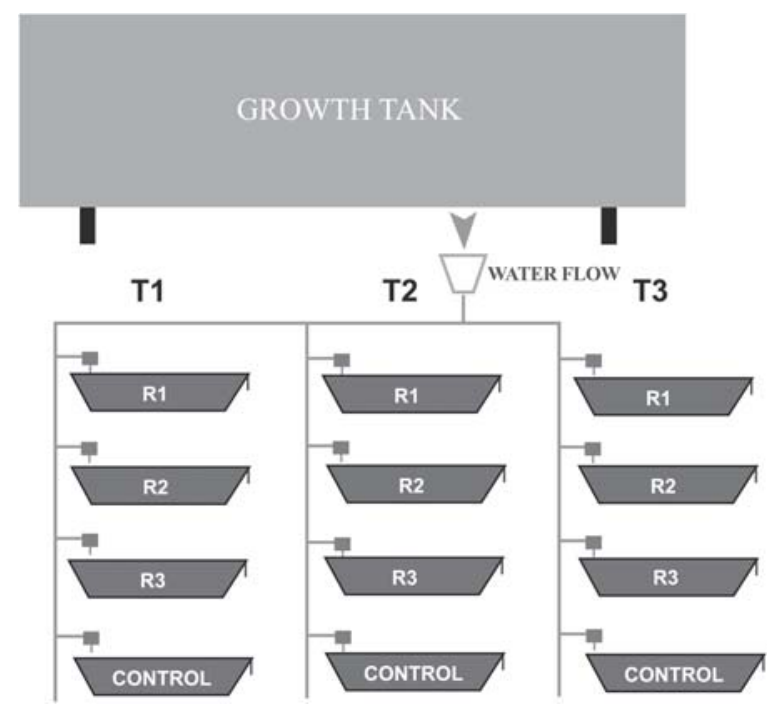

Figure 1. Diagram of the experimental system employed to evaluate utilization of Diplodon chilensis as residual waters depurator on inland water salmonid fish-farms.

Figura 1. Diagrama del sistema experimental empleado para evaluar la utilización de Diplodon chilensis como depurador de aguas residuales de pisciculturas de salmónidos de aguas continentales.

The growth tank contained 5,2k/ $\mathrm{m}^{3}$ of Oncorhynchus mykiss. The trouts were fed daily with $37 \mathrm{~g}$ of fish food (with a composition of $45 \%$ proteins, $30 \%$ lipids and $12 \%$ fibers) during the course of the experiment. The tank water change rate was 0.8 times/hour and that of the trays 0.6 times/hour. The water flood to the tank was $126.6 \mathrm{l} / \mathrm{s}$ while that of the trays system was of 0.007 1/s. The experimental system was kept to an average temperature of $13^{\circ} \mathrm{C}$.

Once the system was set up and after 15 days transcurred for the mussels to adapt to the system, the experiment began. At time 0 the total wet weight (g) (TWW) and length $(\mathrm{cm})(\mathrm{L})$ of each mussel was measured to determine the physiological state of the specimens through the Condition Index (CI) (CI=TWW/L ${ }^{3 * 100)}$.
At the same time water samples from each tray corresponding to the 3 treatments, their respective replicates and controls were taken to determine: total suspended solids (TSS), total dissolved solids (TDS), dissolved oxygen (DO), total phosphorous (TP), ammonium, nitrite, nitrate, conductivity, temperature, $\mathrm{pH}$ and chemical oxygen demand (COD) according to APHA, AWWA, WPCF (1992). In parallel the percentage of organic matter and COD in the substratum of each of the treatment trays and their respective controls were determined. The chemical variables were measured at 0,30 and 60 days, the time established to the experiment duration.

At days 30 and 60, the efficiency percentage of each treatment and controls was determined, according to 
Diplodon chilensis a potential depurator: PARADA, E. ET AL.

the formula (COD influx - outgoing COD / outgoing COD) x 100, where COD influx: concentration of COD of water that flushed from the fish feeding tank; outgoing COD: concentration of COD of water that flushed from treatment trays.

\section{STATISTICALS ANALYSIS}

Normality (Kolmogorov-Smirnov test) and homocedasticity (Barlet test) were verified, and both conditions were not present. The non parametric Kruskall-Wallis test was used to determine differences in the treatments related to the following variables: Among treatments: to analyze the effect of mussel density on water purification capability it was compared physical-chemical values among control and treatments at time 0,30 and 60 days. - Within treatment: to analyze time effect of mussel on water purification capability it were compared values of physical-chemical parameters physical-chemical within each treatment (T1, T2 and T3) during 0, 30 and 60 days.

The "U" Mann-Whitney test was used as multiple comparison test "a posteriori” according to Sokal and Rholf (1997). The differences were considered to be significant at $\alpha$ : 0.05 . The statistical analyses were carried out using the statistical programme XSLAT-Pro 7.5 and SPSS 11.5 .

Through the SPSS 13.0 program it was carried out a covariance analysis (ANCOVA) to verify total wet weight differences ( $\alpha$ : 0.05$)$, independently of their length, reached by the T1, T2 and T3 treatment specimens (density effect) at 0, 30 and 60 day elapsed the experiment.

\section{RESULTS}

Population DESCRIPTION

The length range of the specimens of $D$. chilensis was of 42 to $72 \mathrm{~mm}$, with the modal range between 56 and $60 \mathrm{~mm}$, with an average weight of 18.6g. At the end of the experiment (elapsed 60 days) no increase in the lenght of the specimens of $D$. chilensis was registered, but there was an increase of $2.0 \mathrm{~g}$ in the average weight of the specimens after 30 days of initiated the experiment; at the end of it (60 days) the average weight increased accumulatively to $4.2 \mathrm{~g}$. Fig. 2 shows an increment of the specimens of highest weight after 30 and 60 days of the beginning of the experiment. The ANCOVA shows that weight changes significantly with time in an independent manner from density. On three treatments (T1, T2 and T3) is registered a weight increase which is significantly higher at 60 days of the beginning of the experiment (Table I).

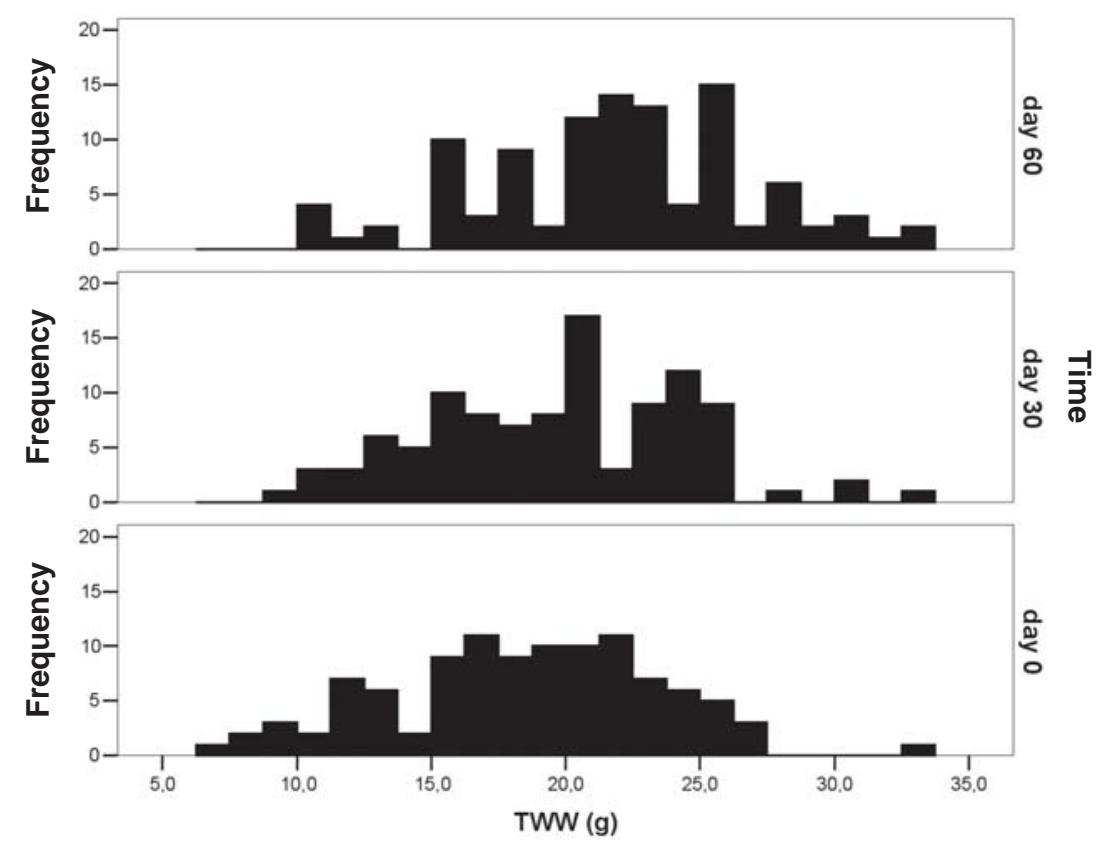

Figure 2. Total wet weight structure of Diplodon chilensis studied population.

FIgURA 2. Estructura del peso húmedo total de la población de Diplodon chilensis estudiada. 
Gayana 72(1), 2008

TABLE I. Variation analysis (ANCOVA) of Diplodon chilensis total weight covariated with its total length in time and density (T1, T2 and T3) (fd = freedom degree; F = Fisher-Snedecor test; $\mathrm{P}$ = probability error).

TABLA I. Análisis de la variación (ANCOVA) del peso total de Diplodon chilensis covariado con su longitud total en el tiempo y densidad (T1, T2 and T3). (fd: grados de libertad, F = prueba de Fisher- Snedecor, P = probabilidad de error).

\begin{tabular}{lrrrc}
\hline Sources & $\mathrm{fd}$ & $\mathrm{F}$ & \multicolumn{1}{c}{$\mathrm{P}$} & Differences \\
\hline Regression & 1.350 & 1032.32 & $<0.001$ & \\
Time & 2.305 & 33.10 & $<0.001$ & \\
Density & 2.305 & 2.30 & 0.102 & \\
Interaction & 4.305 & 0.036 & 0.998 & \\
Time in T1 & & & & \\
Time in T2 & 2.305 & 6.179 & 0.002 & $\mu_{\mathrm{t} 0}=\mu_{\mathrm{t} 30}=\mu_{\mathrm{t} 60,}, \mu_{\mathrm{t} 0}<\mu_{\mathrm{t} 60}$ \\
Time in T3 & 2.305 & 12.688 & $<0.001$ & $\mu_{\mathrm{t} 0}=\mu_{\mathrm{t} 30}<\mu_{\mathrm{t} 60,}, \mu_{\mathrm{t} 0}<\mu_{\mathrm{t} 60}$ \\
\hline
\end{tabular}

The results of the average physiological condition of the specimens measured through the $\mathrm{CI}$ at the beginning of the experiment, after 30 and 60 days in each of the treatments are shown in Table II. The average value of CI of the specimens of T1 increased from 9.2 to 11.2. The specimens of $\mathrm{T} 2$ increased in 1.68, while the specimens of treatment 3 (T3) increased their CI in 1.48. There was no mortality registered at the end of the experiment.

TABLE II. Mean and standard deviation of specimen Condition Index (CI) of each treatment at 0, 30 and 60 days elapsed of the experiment.

Tabla II. Promedio y desviación estandar del Indice de Condición (CI) de los especímenes a 0, 30 y 60 días de transcurrido el experimento.

\begin{tabular}{crrr}
\hline Days & \multicolumn{1}{c}{ T1 } & \multicolumn{1}{c}{ T2 } & \multicolumn{1}{c}{ T3 } \\
\hline 0 & $9.2 \pm 1.6$ & $9.01 \pm 1.1$ & $9.02 \pm 1.4$ \\
30 & $10.1 \pm 1.4$ & $9.9 \pm 1.0$ & $9.8 \pm 2.0$ \\
60 & $11.2 \pm 1.6$ & $10.7 \pm 0.9$ & $10.5 \pm 1.0$ \\
\hline
\end{tabular}

PhysiCAL-CHEMICAL SUBSTRATUM PARAMETERS

The COD values of the trays substratum at the beginning of the experiment (time 0 ) were $4 \mathrm{mgO} / \mathrm{L}$; at the end of the experiment (60 days) the control registered $44.4 \mathrm{mgO} / \mathrm{l}$, whereas, in the treatments the values were $11.9 \mathrm{mgO} / \mathrm{L}$ for $\mathrm{T} 1,11.5 \mathrm{mgO} / \mathrm{L}$ for T2 and $12.1 \mathrm{mgO} / \mathrm{L}$ for T3, elapsed 60 days.
The percentage of organic matter of the trays substratum on each treatment and respective control obtained at the beginning of the experiment and after 30 and 60 days are shown in Table III. The results show that in the control, the organic matter increased 2\% at the end of the experiment. However, in $\mathrm{T} 1$ decreased $0.1 \%$ elapsed 60 days; in $\mathrm{T} 2$ decreased $0.4 \%$ and $0.5 \%$ in $\mathrm{T} 3$.

TABLE III: Organic matter percentage in trays substrate of each treatment (T1, T2 and T3) and respective controls.

TABLA III: Porcentaje de material orgánica del sustrato de las cubetas de cada tratamiento (T1, T2 y T3) y sus respectivos controles.

\begin{tabular}{ccccc}
\hline Time (days) & Control & T1 & T2 & T3 \\
\hline 0 & $2.4 \pm 0.3$ & $1.6 \pm 0.01$ & $1.7 \pm 0.1$ & $2.0 \pm 0.1$ \\
30 & $2.9 \pm 0.3$ & $1.2 \pm 0.2$ & $1.1 \pm 0.1$ & $1.4 \pm 0.2$ \\
60 & $4.4 \pm 1.8$ & $1.5 \pm 0.1$ & $1.3 \pm 0.1$ & $1.5 \pm 0.1$ \\
\hline
\end{tabular}




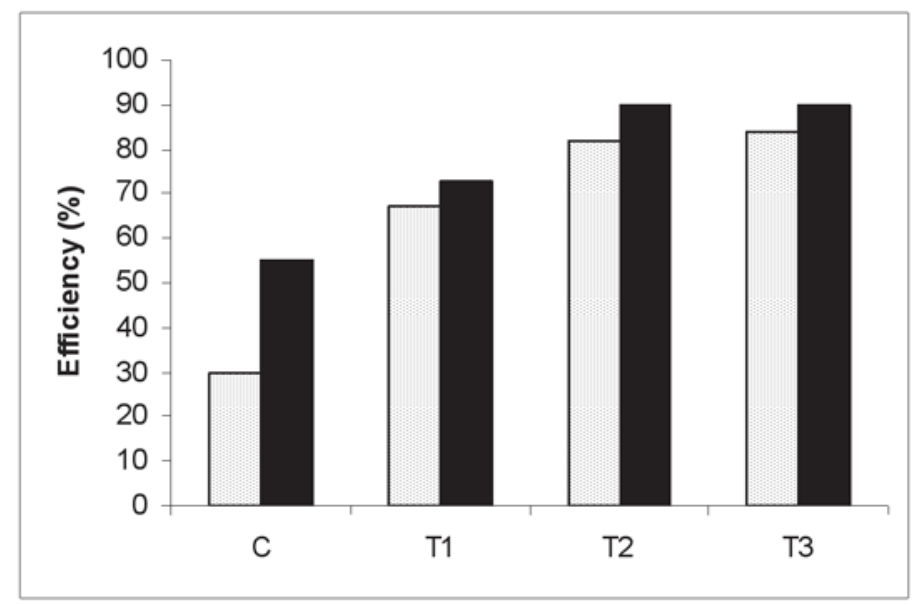

FIGURE 3. Comparison of efficiency percentage among the three treatments and controls at 30 and 60 days of elapsed the experiment (dotted: day 30, black: day 60).

Figura 3. Porcentaje de eficiencia entre los tres tratamientos y controles respectivos a los 30 y 60 días de transcurrido el experimento (punteado:día 30, negro:día 60).

PhySICAL-CHEMICAL WATER PARAMETERS

The physical and chemical parameters values registered in water that flowed out from each of the trays (control and treatments) at the beginning of the experiment and after 30 and 60 days once the experiment ended, are shown in Table IV.

The total suspended solids (TSS) values registered at the beginning of the experiment ( 0 days) fluctuated from 0,067 to $0,093 \mathrm{mg} / \mathrm{L}$ considering control and treatments. At 30 days of the experiment the values obtained in the treatments decreased in all of them. The treatment with lower mussel density registered the lowest values $(0,002 \mathrm{mg} / \mathrm{L})$. The control values were considerably higher than the treatments. At the end of the experiment (60 days) the values of the different treatments are the same among each other and very similar to those obtained after 30 days, increasing only in the controls (Table IV). Differences registered are significant according to Kruskal-Wallis and Mann-Whitney's U test (Tables IV, V and VIIb). The total dissolved solids (TDS) and dissolved oxygen (DO) showed similar values in the experimental system at day 0, 30 and 60 (Table IV). Regarding the total phosphorous (TP) values, the controls as well as the treatment $\mathrm{T} 1$, did not show differences at the beginning of the experiment, and after 30 and 60 days. However, noteworthy reductions were registered in T2 and T3 at the end of the experiment (60 days). Kruskal-Wallis and MannWhitney's U test show significant differences among treatment and control only after 30 days past the experiment and also between T1 and T3 as well as between T2 and T3 (Tables IV, V and VIIb).

The ammonium registered significant differences among controls and treatments elapsed 30 days of the experiment (Tables V, VI and VIIb). However, there was a tendency of the value to increase along time in the control trays (Table IV).

The nitrite registered significant differences among controls and treatment at day 30 and 60 of the experiment (Tables IV, V, VI and VIIa). The values of nitrate remained without variations in the three treatments, and in the respective controls during the time the experiment lasted (Table IV).

The values of COD registered in the treatments showed significative differences in function of mussel density and the time (day 30 and 60) they remained in the trays (IV, V, VI and VIIa). 
Gayana 72(1), 2008

TABLE IV. Mean and standard deviation of water physical-chemical parameters from controls (C) and treatments (T) at 0,30 and 60 days. (TSS: total suspended solids; TDS: total dissolved solids; DO: dissolved oxygen; TP: total phosphorous; COD: chemical oxygen demand).

TABLa IV. Promedio y desviación estándar de los parámetros físico-químicos del agua de los controles (C) y tratamientos a los 0, 30 y 60 días (TSS: sólidos totales suspendidos; TDS: sólidos totales disueltos; DO: oxígeno disuelto; TP fósforo total; COD: demanda química de oxígeno).

\begin{tabular}{|c|c|c|c|c|}
\hline $\begin{array}{l}\text { Parameters } \\
\text { days TSS (mg/L) }\end{array}$ & $\mathrm{C}$ & $\mathrm{T} 1$ & $\mathrm{~T} 2$ & T3 \\
\hline 0 & $0.067 \pm 0.02$ & $0.093 \pm 0.02$ & $0.093 \pm 0.05$ & $0.08 \pm 0$ \\
\hline 30 & $0.2 \pm 001$ & $0.002 \pm 0$ & $0.005 \pm 0$ & $0.005 \pm 0.001$ \\
\hline 60 & $0.4 \pm 0,01$ & $0.003 \pm 0$ & $0.003 \pm 0$ & $0.003 \pm 0.003$ \\
\hline \multicolumn{5}{|l|}{ TDS (mg/L) } \\
\hline 0 & $81 \pm 2.7$ & $84 \pm 0.6$ & $83 \pm 2.3$ & $83 \pm 0.6$ \\
\hline 30 & $76 \pm 0$ & $77 \pm 0.6$ & $76 \pm 1.5$ & $76 \pm 1.7$ \\
\hline 60 & $90 \pm 1$ & $89 \pm 0$ & $89 \pm 0$ & $89 \pm 0.6$ \\
\hline \multicolumn{5}{|l|}{$\mathrm{DO}(\mathrm{mg} / \mathrm{L})$} \\
\hline 0 & $7.3 \pm 0.06$ & $7.3 \pm 0.06$ & $7.5 \pm 0$ & $7.4 \pm 0.2$ \\
\hline 30 & $6.8 \pm 0.1$ & $7.9 \pm 0.1$ & $7.8 \pm 0.1$ & $7.8 \pm 0.1$ \\
\hline 60 & $6.8 \pm 0.1$ & $7.5 \pm 0.1$ & $7.3 \pm 0.1$ & $7.4 \pm 0.1$ \\
\hline \multicolumn{5}{|l|}{$\mathrm{TP}(\mathrm{mg} / \mathrm{L})$} \\
\hline 0 & $0.5 \pm 0.8$ & $0.1 \pm 0$ & $0.1 \pm 0.1$ & $0.1 \pm 0.1$ \\
\hline 30 & $0.6 \pm 0.1$ & $0.2 \pm 0$ & $0.3 \pm 0.1$ & $0.1 \pm 0.1$ \\
\hline 60 & $0.5 \pm 0.2$ & $0.1 \pm 0$ & $0.01 \pm 0.02$ & $0.03 \pm 0.03$ \\
\hline \multicolumn{5}{|l|}{ Ammonium (mg/L) } \\
\hline 0 & $0.04 \pm 0.003$ & $0.04 \pm 0.01$ & $0.05 \pm 0.01$ & $0.04 \pm 0.01$ \\
\hline 30 & $0.2 \pm 0.1$ & $0.02 \pm 0.01$ & $0.02 \pm 0,1$ & $0.02 \pm 0.004$ \\
\hline 60 & $0.2 \pm 0.1$ & $0.06 \pm 0.05$ & $0.04 \pm 0.02$ & $0.05 \pm 0.03$ \\
\hline \multicolumn{5}{|l|}{ Nitrite (mg/L) } \\
\hline 0 & $0.005 \pm 0.002$ & $0.004 \pm 0.002$ & $0.003 \pm 0.001$ & $0.004 \pm 0$ \\
\hline 30 & $0.6 \pm 0.03$ & $0.3 \pm 0.04$ & $0.3 \pm 0.1$ & $0.4 \pm 0.04$ \\
\hline 60 & $0.3 \pm 0.1$ & $0.03 \pm 0.01$ & $0.03 \pm 0.001$ & $0.03 \pm 0$ \\
\hline \multicolumn{5}{|l|}{ Nitrate (mg/L) } \\
\hline 0 & $0.2 \pm 0.1$ & $0.1 \pm 0.02$ & $0.03 \pm 0.1$ & $0.02 \pm 0.03$ \\
\hline 30 & $0.003 \pm 0$ & $0.002 \pm 0$ & $0.002 \pm 0$ & $0.002 \pm 0$ \\
\hline 60 & $0.004 \pm 0$ & $0.002 \pm 0$ & $0.003 \pm 0.001$ & $0.003 \pm 0.001$ \\
\hline \multicolumn{5}{|l|}{ Conductivity ( $\mu g)$} \\
\hline 0 & $171.2 \pm 2.4$ & $170.2 \pm 6.0$ & $169 \pm 3.9$ & $172.4 \pm 1.8$ \\
\hline 30 & $165 \pm 0.8$ & $163 \pm 0.04$ & $161 \pm 1.1$ & $160 \pm 1.8$ \\
\hline 60 & $191 \pm 2$ & $170 \pm 0$ & $171 \pm 0.001$ & $170,4 \pm 4$ \\
\hline \multicolumn{5}{|l|}{$\mathrm{pH}$} \\
\hline 0 & $7.3 \pm 0$ & $7.2 \pm 0,1$ & $7.2 \pm 0.02$ & $7.2 \pm 0.05$ \\
\hline 30 & $7.1 \pm 0.1$ & $7.3 \pm 0.2$ & $7.3 \pm 0.1$ & $7.3 \pm 0.1$ \\
\hline 60 & $7.5 \pm 0.1$ & $7.3 \pm 0.1$ & $7.2 \pm 0.1$ & $7.3 \pm 0.1$ \\
\hline \multicolumn{5}{|l|}{ COD (mgO/L) } \\
\hline 0 & $24 \pm 8$ & $16 \pm 14$ & $12 \pm 11$ & $12 \pm 9$ \\
\hline 30 & $16.1 \pm 1.1$ & $8.1 \pm 0$ & $8.7 \pm 1.2$ & $4.7 \pm 1.2$ \\
\hline 60 & $26.9 \pm 2.3$ & $9.4 \pm 2$ & $6.7 \pm 4.6$ & $4 \pm 0$ \\
\hline
\end{tabular}

TREATMENT EFFICIENCY

The percentage of treatment efficiency of 15(T1), 30(T2) and 60(T3) specimens respectively was calculated using the values corresponding to the COD registered in the water flowing out from the control trays and that from treatment trays. These values allowed to determine which of the treatment is the most efficient. The results show that the percentage of efficiency of the systems is higher than $90 \%$, increasing with density and the time that the experiment lasted (Fig. 2).

\section{DISCUSSION}

The results of the present study show that Diplodon chilensis would be a qualified species to be used as biofilter for depuration of residual waters of fish 
farming processes in freshwater. The results show that $100 \%$ of the specimens used survived the experiment and all of them improved their weight and their physiological condition. The CI values obtained from the mussels exposed to the treatments are higher than those obtained by Peredo et al. (2006) in experiments of relocation carried out with specimens from the same population. The difference would be explained by the food disponibility that they would have obtained due to the filtration of organic components present in the residual waters which is corroborated by the significant weight increase of the specimens during treatments (Table I, Fig. 1). Concurrently, the values of the CI observed in the present study are significant higher than those reported by Lara and Parada (1991) for specimens that live in oligotrophic waters.

The physical and chemical analysis of the residual waters exposed to the action of the mussels compared to the control and the water that flows out from the trout growth tanks show that the levels of several parameters were significantly reduced. Within these parameters it was proved that $D$. chilensis showed more efficiency in diminishing the total suspended solids (TSS), total phosphorous (TP), nitrite and the chemical oxygen demand (COD). These value decreases were related to mussel density and to the time that they remained in the treatment when compared with the values obtained in the control trays, thus showing the effect that the mussels exert on the system. Other parameters such as TDS, DO, conductitity and $\mathrm{pH}$ did not show significant changes in their values in the experimental system (control and treatments) (Table IV).

According to statistical analysis, there was a significant decrease in TSS, nitrate and COD and increase in ammonium values in function of mussel density and time of the experiment running. These significative value changes were registered from day 30 of the experiment (Tables IV, V, VI and VIIa, b).

TABLE V. Kruskal-Wallis test values for time (0, 30 and 60 days) and density (T1: 15 specimens; T2: 30 specimens and T3: 60 specimens). Only those parameters with significant differences are shown (TSS: total suspended solids; COD: chemical oxygen demand; TP: total phosphorous)(P value: $<0.05)$.

Tabla V. Valores del test Kruskal-Wallis para tiempo transcurrido del experimento $(0,30$ y 60 días) y densidad de especímenes (T1: 15, T2: 30 y T3: 60). Sólo se muestran parámetros con diferencias significativas.(TSS: sólidos totales suspendidos; COD: demanda química de oxígeno; TP: total fósforos) $(\mathrm{P}<0.05)$.

\begin{tabular}{lcccccc}
\hline & \multicolumn{3}{c}{ Time } & \multicolumn{3}{c}{ Density } \\
\hline Parameters & day 0 & day 30 & day 60 & T1 & T2 & T2 \\
TSS & ns & 0.035 & ns & 0.01 & 0.019 & 0.01 \\
COD & ns & 0.017 & 0.028 & 0.04 & 0.034 & 0.019 \\
Nitrite & ns & 0.03 & 0.042 & 0.007 & 0.007 & 0.006 \\
TP & ns & 0.022 & ns & ns & ns & ns \\
Ammonium & ns & 0.039 & ns & 0.032 & 0.024 & 0.021 \\
\hline
\end{tabular}

TABLE VI. Mann-Whitney’ U test showing significant differences among treatments and controls and among treatments at 0,30 and 60 days on each treatment (T1,T2 and T3). Only those parameters with significant differences are shown. (TSS: total suspended solids; COD: chemical oxygen demand). ( $P$ value: $<0.05)$.

TABLA VI. Valores del test U de Mann-Whitney que muestra diferencias significativas entre tratamientos y controles y entre tratamientos a 0, 30 y 60 días de cada tratamiento (T1, T2 y T3). Solo se muestran los parámetros con diferencias significativas.(TSS: sólidos totales suspendidos, COD: demanda química de oxígeno). $(P<0.05)$.

\begin{tabular}{lrrrrrrrrrrrr}
\hline Parameters & \multicolumn{3}{c}{ COD } & \multicolumn{4}{c}{ Nitrite } & \multicolumn{4}{c}{ Ammonium } & \multicolumn{2}{c}{ TSS } \\
\hline Comparisons & T1 & T2 & T3 & T1 & T2 & T3 & T1 & T2 & T3 & T1 & T2 & T3 \\
C d0 - Td0 & ns & ns & ns & ns & ns & ns & ns & ns & ns & ns & ns & ns \\
C d0 - Td30 & 0.037 & 0.046 & 0.046 & 0.037 & 0.046 & 0.037 & 0.043 & 0.034 & 0.043 & 0.046 & 0.043 & 0.043 \\
C d0 - Td60 & 0.046 & 0.046 & 0.037 & 0.047 & 0.046 & 0.037 & ns & ns & ns & 0.043 & 0.046 & 0.046 \\
C d30 - Td0 & ns & ns & ns & 0.046 & 0.046 & 0.037 & 0.034 & 0.037 & 0.034 & ns & ns & 0.037 \\
C d30 - Td30 & 0.046 & 0.046 & 0.046 & 0.034 & 0.043 & 0.034 & 0.034 & 0.025 & 0.034 & 0.05 & 0.046 & 0.046 \\
C d30 - Td60 & 0.046 & 0.046 & 0.037 & 0.043 & 0.043 & 0.034 & 0.037 & 0.037 & 0.037 & 0.046 & 0.05 & 0.05 \\
C d60 - Td0 & 0.043 & 0.046 & 0.034 & 0.05 & 0.05 & 0.037 & ns & ns & ns & 0.046 & ns & 0.037 \\
\hline
\end{tabular}


Gayana 72(1), 2008

\begin{tabular}{|c|c|c|c|c|c|c|c|c|c|c|c|c|}
\hline \multirow{2}{*}{$\begin{array}{l}\text { Parameters } \\
\text { Comparisons }\end{array}$} & \multicolumn{3}{|c|}{ COD } & \multicolumn{3}{|c|}{ Nitrite } & \multicolumn{3}{|c|}{ Ammonium } & \multicolumn{3}{|c|}{ TSS } \\
\hline & $\mathrm{T} 1$ & $\mathrm{~T} 2$ & T3 & T1 & $\mathrm{T} 2$ & T3 & T1 & $\mathrm{T} 2$ & T3 & T1 & $\mathrm{T} 2$ & T3 \\
\hline C d60 - Td30 & 0.037 & 0.043 & 0.046 & ns & ns & ns & ns & 0.034 & 0.043 & ns & ns & ns \\
\hline C d60 - Td60 & 0.043 & 0.043 & 0.037 & 0.046 & 0.046 & 0.037 & 0.037 & ns & ns & ns & ns & ns \\
\hline T d0 - T d30 & ns & ns & ns & 0.037 & 0.046 & 0.025 & 0.043 & 0.037 & 0.043 & 0.043 & 0.043 & 0.034 \\
\hline T d0 - T d60 & ns & ns & 0.025 & 0.046 & 0.046 & 0.025 & ns & ns & ns & 0.043 & 0.046 & 0.037 \\
\hline $\mathrm{T} \mathrm{d} 30$ - T d60 & ns & ns & 0.025 & 0.034 & 0.043 & 0.025 & ns & ns & ns & ns & ns & ns \\
\hline
\end{tabular}

TABLE VIIa. Mann-Whitney's U test showing significative differences among treatments and respective controls and among treatments $(\mathrm{T} 1, \mathrm{~T} 2, \mathrm{~T} 3)$ for chemical oxygen demand (COD) and nitrite at 0,30 and 60 days. (P value: $<0.05)$.

TABLA VIIa. Valores del test U de Mann-Whitney que muestra diferencias significativas entre tratamientos y controles respectivos y entre tratamientos $(\mathrm{T} 1, \mathrm{~T} 2, \mathrm{~T} 3)$ para la demanda química de oxígeno (COD) y nitrito a los 0,30 y 60 días. $(\mathrm{P}<0.05)$.

\begin{tabular}{lcccccc}
\hline & & COD & \multicolumn{3}{c}{ Nitrite } \\
\hline Comparisons & day 0 & day 30 & day 60 & day 0 & day 30 & day 60 \\
C-T1 & ns & 0.037 & 0.043 & 0.046 & 0.034 & 0.046 \\
C-T2 & ns & 0.046 & 0.043 & 0.046 & 0.043 & 0.043 \\
C-T3 & ns & 0.046 & 0.034 & 0.046 & 0.034 & 0.037 \\
T1-T2 & ns & ns & ns & ns & ns & ns \\
T1-T3 & ns & 0.034 & 0.034 & ns & 0.025 & ns \\
T2-T3 & ns & ns & ns & ns & ns & ns \\
\hline
\end{tabular}

TABLE VIIb. Mann-Whitney’s U test showing significative differences among treatments and respective controls and among treatments at day 30 of the experiment for total suspended solids (TSS), total phosphorous (TP) and ammonium. (P value: < 0.05).

TABLA VIIb. Valores del test U de Mann-Whitney que muestra diferencias significativas entre tratamientos y controles respectivos y entre tratamientos a los 30 días de transcurrido el experimento para sólidos totales suspendidos (TSS), fósforo total (TP) y amonio. ( $<<0.05)$.

\begin{tabular}{cccc}
\hline day 30 & TSS & TP & Ammonium \\
\hline C-T1 & 0.05 & 0.05 & 0.034 \\
C-T2 & 0.046 & 0.05 & 0.025 \\
C-T3 & 0.046 & 0.05 & 0.034 \\
T1-T2 & ns & ns & ns \\
T1-T3 & ns & 0.05 & ns \\
T2-T3 & ns & 0.05 & ns \\
\hline
\end{tabular}

On the other hand, other parameters such ammonium, increased in function of the time exposed rather than density due, probably, to the mineralization of the organic matter and the subsequent regulation of nutrients in the interface sediment-water (Hargreaves 1997) and to the role that $D$. chilensis perform in the nitrogen cycle (Soto \& Mena 1999).

Reeders and Bij de Vaate (1990) point out that in Dreissena polimorpha the filtration activity is temperature indeferent between $5-20^{\circ} \mathrm{C}$. At low temperature the filtration rate drops abruptly. At high temperature gradual inhibition occurs. In this study the well water used ketp a constant temperature at $13^{\circ} \mathrm{C}$. Therefore, in the present study it was not possible to evaluate the influence of this parameter. The accumulation of organic matter in the substratum was higher in the controls, duplicating the amount after 60 days of the experiment. Undoubtly, these results are related to absence of mussels. In contrast, the levels of organic matter in the treatments did not show significant differences in time, being lower than in the controls. The aforementioned is corroborated by the results of CDO registered in the substratum at the beginning and at the end of the experiment. The differences in values of organic matter and COD between controls and treatments is attributable to the filtering efficiency of $D$. chilensis and that uses the organic matter of the water column as well as the substratum for feeding (Valdovinos \& Cuevas 1996; Lara et al. 2002b). These results are corroborated by the increase in weight and in the condition index of the specimens. The low percentages of the organic 
matter registered in the substratum could be atributable to fecal or seudofecal material of mussels (Table II). The values obtained in the treatments as well as in the controls in water COD data, show a high efficiency percentage of the system (Fig. 2). However, these results could lead to overvalue the mussel's efficiency. The controls show a 30 and 55\% efficiency of purification of the water after 30 and 60 days elapsed from the onset of the experiment, values that obviously cannot be attributable to the action of the specimens but to the sedimentation in the substratum, which is corroborated by the values of organic matter and COD. The decrease of organic matter and the values of COD in the substratum of the treatments respect to the controls allow us to establish that the real efficiency percentages of the system implemented would be 37, 52 and 54\% for treatments T1, T2 and T3, respectively after 30 days and of 17.6, 35 and 35\% for treatments T1, T2 and T3, respectively after 60 days. From the above stated it can be inferred that the density of the specimens and the time constitute important variables to consider at the time of implementing the system. The maintenance of the obtained COD value in the treatment with 60 specimens (T3), at 30 and 60 days, would show that mussel density is an important aspect in the efficiency of the system, which would imply to take into consideration a more frequent change of specimens if a larger scale project is implemented.

It must make clear that the results of the present study are valid to an experimental system scale. The results obtained in the present study show that $D$. chilensis is a suitable species to be used in low scale fish-farming i.e. rural fish farming. The implementation of a higher scale system implies to take into consideration a series of aspects in order to not endanger the sustentability of the natural systems. Studies carried out on $D$. chilensis have shown that this native species is an important component in the freshwater systems of Southern Chile, due to its biomass and abundance and for the role that accomplishes in the oligotrophy of the lake systems. As mentioned before two aspects: extraction and transportation of the specimens and the risk of disturbance that would occur in natural ecosystems if there is an acute decrease in the number of specimens in the natural populations, are important to keep in mind for a greater scale system to be implemented.

Regarding the transportation, relocation studies of D. chilensis (Peredo et al. 2005; Parada \& Peredo 2005; Peredo et al. 2006), show that the relocation of these species is possible to carry out taking care of the appropiate manipulation of the specimens during the capture and transportation, the time of the year as well as the habit requirements of the species in the place of relocation, among others. Another important aspect to evaluate is the effect of sanitary treatment residues upon mussels carried out by fish farming. In relation to the number of specimens extracted there are no studies that support the consequences that would be produced in the natural environment. However, given the characteristics of their life cycle and their slow growth rate (Parada et al. 1989), the impact on the natural systems will depend on the amount of specimens extracted. The aforementioned deserves exploring the possibility to cultivate these species, allowing having a stock without having to alter the natural systems. This issue has not been studied up to now.

As mentioned before, the results of the present study allow to conclude that Diplodon chilensis would be an effective biofilter for residual waters of fish farms. In addition, show that the use of $D$. chilensis constitutes a low cost biological solution to the problem of environmental impact produced at present by the fish farming industry on water quality. Its use would be advisable for the purification of residual waters of low scale fish farming centers, with implementation of other previous studies, such as culture feasibily of $D$. chilensis, before being used in industrial fish farming.

\section{ACKNOWLEDGMENTS}

We are grateful to David Figueroa-Hernández for his valuable suggestions on the manuscript, to Gladys Lara and Patricio de los Ríos for their assistance in the statistical analysis of data, to the anonymous reviewer for his valuable suggestions to improve this paper and to Dirección General de Investigación, Catholic University of Temuco, Chile (Project 2005-4-03) for financial support.

\section{BIBLIOGRAPHY}

APHA, AWWA \& WPCF. 1992. Standard methods for the examination of water and wastewater. Edition $19^{\text {th }}$.

Beveridge, M.C.M. 1996. Cage Aquaculture. $2^{\text {nd }}$ edn. Fishing News Book. Oxford, England.

Bunt, C., H. Mac Isaac, \& W.G. Sprules, 1993. Pumping rates and projected filtering impact of juvenile 
Zebra mussel (Dreissena polymorpha) in Western Lake Erie. Canadian Journal of Fisheries and Aquatic Sciences 50: 1017-1022.

Dame, R., N. Dankers ,T. Prins , H. Jongsma \&.S. SMAAL 1991. The influence of mussel bed on nutrients in the Western Wadden Sea and Eastern Scheldt Estuaries. Estuaries 14: 130-138.

Elser, J.J. D.R. Dobberfuhl, N.A. Mackay \& J.H. SCHAMPEL 1996. Organism size, life history, and $\mathrm{N}$ : P stoichiometry: toward a unified view of cellular and ecosystemic proceses. Bioscience 46: 694-684.

Griffiths, R.W., D. Schloesser, J.H. Leach \& W.P. KovalaK. 1991. Distribution and Dispersal of the Zebra mussel (Dreissena polymorpha) in the Great lakes Region. Canadian Journal of Fisheries and Aquatic Sciences 48: 1381-1388.

HAAMER, J.1996. Improving Water Quality in a Eutrophied Fjord System with Mussel Farming. Ambio 25(5): 356-362.

Herber, P.D.N., C.C. Wilson, M.H. Murdoch \& R. LaZaR 1991. Demography and ecological impacts of the invading mollusk, Dreissena polymorpha. Canadian Journal of Zoology 69: 405-409.

Lara, G. \& E. Parada 1991. Seasonal changes in the condicion index of Diplodon chilensis chilensis (Gray 1828) in sandy and muddy substrata. Villarrica Lake (39¹8'S; $72^{\circ} 05^{\prime}$ W). Boletín Sociedad Biología de Concepción 62: 99-106.

Lara, G., A. Contreras \& F. Encina. 2002a. La almeja de agua dulce Diplodon chilensis (Bivalvia: Hyriidae) potencial biofiltro para disminuir los niveles de coniformes fecales en pozos: experimentos de laboratorio. Gayana 66(2): 113-118.

Lara, G., E. Parada \& S. Peredo. 2002b. Alimentación y conducta alimentaria de la almeja de agua dulce Diplodon chilensis (Bivalvia: Hyriidae). Gayana 66(2): 107-112.

López, D., A. Buschmann \& M. GonzÁLEz. 1988. Efectos del suelo de las zonas costeras por prácticas de Acuicultura. Medio Ambiente 9(1): 42-54.

Parada, E. \& S. Peredo. 2002. Estado actual de la taxonomía de bivalvos dulceacuícolas chilenos: progresos y conflictos. Revista Chilena de Historia Natural 75: 691-701.

Parada, E. \& S. Peredo. 2005. La relocalización como una herramienta de conservación y manejo de la biodiversidad. Lecciones aprendidas con Diplodon chilensis (Gray 1828) (Bivalvia: Hyriidae). Gayana 69(1): 41-47.
Parada, E., S. Peredo, G. Lara \& I.Valdebenito. 1989. Growth, age and life span of the freshwater mussel Diplodon chilensis chilensis (Gray, 1828). Archiv für Hydrobiologie 115(4): 563-573.

Parada, E., S. Peredo, J. Valenzuela \& D. Manuschevich. 2007. Extention of the current northern distribution range of freshwater mussel Diplodon chilensis (Gray, 1828) (Bivalvia: Hyriidae) in Chile. Gayana 71(2): 212-215.

Peredo, S., E. Parada, I. Valdebenito \& M. Peredo. 2005. Relocation of the freshwater mussel Diplodon chilensis (Hyriidae) as a strategy for its conservation and management. Journal of Molluscan Studies. 71 (1): 195-198.

Peredo, S., E. Parada, I. Valdebenito \& M. Peredo. 2006. Effect of aerial exposure on physiological condition and survival of Diplodon chilensis (Bivalvia: Hyriidae) during translocation. Malacologia 49(1):217-221.

PoniaK, J., S. Muñoz, N. Díaz, C. González \& I. Diaz 2004. Efecto de dietas con diferentes proporciones de proteínas y lípidos sobre la respuesta productiva y características de la canal del salmón del Pacífico (Oncorhynchus kisutch). Archivos de Medicina Veterinaria 36(2):163-172.

Reeders, H. H., A. Bij de Vaate \& F.J. Slim. 1989. The filtration rate of Dreissena polymorpha (Bivalvia) in three Dutch lakes with reference to biological water quality management. Freswater Biology 22:133-141.

Reeders, H. H. \& A. Bij De VaAte. 1990. Zebra mussel (Dreissena polymorpha): A New Perspective For Water Quality Management. Hydrobiologia 2000/ 2001: 437-450.

Sokal, R. R. \& F.J. Rholf. 1997. Biometry. The principles and practice of statistics in biological research. Third Edition. W. H. Freeman \& Company, New York, 887 pp.

Soto, D., \& G. Mena. 1999. Filter feeding by the freshwater mussel Diplodon chilensis, as a biocontrol of salmon farming eutrophication. Aquaculture 171: 65-81.

Soто, D. 2002. Oligotrophic patterns in southern Chilean lakes: the relevance of nutrients and mixing depth. Revista Chilena de Historia Natural 75:377-393.

VAlDovinos, C. \& R.R. Cuevas. 1996. Tasas de aclarancia de Diplodon chilensis (Bivalvia: Hyriidae): un suspensívoro bentónico dulceacuícola de Chile Central. Medio Ambiente 13(1): 114-118. 